\title{
Pemantauan Kerentanan Fisik di Pesisir Kabupaten Demak (Studi Kasus Perubahan Garis Pantai)
}

\section{Theresa Pinkan Gustya Primasti ${ }^{1 *}$, Hariyadi ${ }^{1}$, Baskoro Rochaddi ${ }^{1}$, Sugeng Widada ${ }^{1}$ dan Rikha Widiaratih ${ }^{1}$}

\author{
${ }^{1}$ Departemen Oseanografi, Fakultas Perikanan dan Ilmu Kelautan, Universitas Diponegoro \\ Jl. Prof. H. Soedarto, SH, Tembalang Semarang. 50275 Telp/Fax (024) 7474698 \\ *Email: theresapgp@students.undip.ac.id
}

\begin{abstract}
Abstrak
Wilayah pesisir Kabupaten Demak yang berada di bagian pantai utara Jawa merupakan wilayah yang rentan terhadap bencana. Kabupaten Demak yang awalnya memiliki sektor pertanian yang maju kini berubah menjadi kawasan industri, pemukiman dan pembangunan. Oleh karena itu, diperlukan suatu kajian untuk menentukan tingkat kerentanan fisik wilayah pesisir di Kabupaten Demak yang meliputi parameter geomorfologi, elevasi, perubahan garis pantai, pasang surut, kenaikan muka air laut dan gelombang. Tujuan penelitian ini adalah untuk menentukan indeks kerentanan pesisir Kabupaten Demak yang difokuskan pada analisa dan evaluasi perubahan garis pantai. Metode yang digunakan dalam penelitian ini adalah metode Coastal Vulnerability Index (CVI) yang diadaptasi oleh United States Geological Suveys (USGS) yang dibagi menjadi lima kategori kerentanan pesisir Wiayah Pesisir Kabupaten Demak terbagi menjadi 2 kategori kerentanan yaitu Rentan yang berada di Kecamatan Bonang, Kecamatan Karang Tengah dan Kecamatan Sayung. Sedangkan untuk kategori Sedang berada di Kecamatan Wedung. Hasil perhitungan variable fisik yakni geomorfologi, elevasi, perubahan garis pantai, pasang surut, kenaikan muka air laut dan gelombang menunjukkan bahwa parameter yang berpengaruh besar terhadap kerentanan wilayah pesisir Kabupaten Demak adalah perubahan garis pantai. Kecenderungan perubahan garis pantai di pesisir Kabupaten Demak yaitu erosi pantai dibandingkan akresi. Setiap desa di sepanjang Pesisir Kabupaten Demak mengalami tren kenaikan perubahan garis pantai baik abrasi maupun akresi.
\end{abstract}

Kata kunci : Kerentanan, CVI, perubahan garis pantai, DSAS

\begin{abstract}
The coastal area of Demak Regency, which is located on the northern coast of Java, is a disaster-prone area. Demak Regency, which originally had an advanced agricultural sector, has now turned into an industrial, residential and development area. Therefore, a study is needed to determine the level of physical vulnerability of coastal areas in Demak Regency which includes geomorphological parameters, elevation, shoreline changes, tides, sea level rise and waves. The purpose of this study was to determine the coastal vulnerability index of Demak Regency which is focused on the analysis and evaluation of shoreline changes. The method used in this research is the Coastal Vulnerability Index (CVI) method adapted by the United States Geological Suveys (USGS) which is divided into five categories of coastal vulnerability. The coastal area of Demak Regency is divided into 2 categories of vulnerability, namely Vulnerable category in Bonang District, Karang Tengah District and Sayung District. As Medium for the category, it is in the Wedung District. The results of the calculation of physical variables, namely geomorphology, elevation, shoreline changes, tides, sea level rise and waves show the parameters that have a big influence on the vulnerability of coastal area of Demak Regency are changes in the coastline. The trend of shoreline change in Demak Regency is coastal erosion compared to accretion. Every village along the Coastal Zone of Demak Regency has experienced an upward trend in shoreline changes, both abrasion and accretion.
\end{abstract}

Keywords : Vuknerability, CVI, shoreline changes, DSAS

\section{PENDAHULUAN}

Wilayah pesisir menjadi wilayah yang menjadi pusat aktivitas manusia dan relatif mudah untuk dijangkau (Marfai dan King, 2008). Namun wilayah pesisr juga merupakan wilayah pesisir yang lemah atau rentan terhadap faktor lingkungan seperti perubahan iklim diantaranya kenaikan muka air laut. Kenaikan muka air laut dapat berpengaruh pada perubahan ondisi fisik di suatu wilayah pesisir. 
Perubahan kondisi ini memberikan dampak merugikan bagi masyarakat di wilayah pesisir seperti banjir rob, perubahan garis pantai, juga erosi pantai.

Peristiwa erosi pantai (abrasi) dan rob sering terjadi di pesisir Kabupaten Demak dimana Desa Morodemak menjadi desa paling parah mendapat dampak akibat kenaikan muka air laut ini. Kerugian yang ditimbulkan akibat erosi pantai, pesisir Demak telah mengalami kemunduran garis pantai hingga 30,4 kilometer pada tahun 2016. Tidak hanya itu lahan tambak yang semula digunakan warga pesisir Demak untuk bekerja telah hilang seluas 640 hektar akibat abrasi (Sanjoto et al., 2016). Tak hanya itu keadaan pemukiman yang kumuh dan tergenang air saat rob mengakibatkan terganggunya aktifitas warga di daerah setempat.

Upaya mencegah dampak yang ditimbulkan akibat bencana di kawasan pesisir dapat dilakukan dengan melakukan analisis kerentanan wilayah tersebut. Penentuan kerentanan wilayah pesisir dapat dilakukan dengan penilaian terhadap kondisi fisik daerah pesisir. Salah satu metode yang dapat digunakan ialah CVI (Coastal Vulnerability Index). CVI adalah metode ranking relatif berbasis skala indeks dari parameter fisik seperti: Geomorfologi, Perubahan Garis Pantai, Elevasi, Pasang Surut, Kenaikan Muka Air Laut, dan Tinggi Gelombang (Kasim et al., 2012).

Dampak yang diterima wilayah pesisir akibat fenomena ini merupakan hal yang perlu dikaji untuk mengidentifikasi secara spasial tingkat kerentanan pantai dan memproyeksikan perubahan kerentanan wilayah pesisir di masa yang akan datang. Nilai indeks kerentanan atau CVI ini kemudian diidentifikasi secara spasial tingkat kerentanan pantai untuk memperkirakan perubahan kerentanan wilayah pesisir di masa yang akan datang. Oleh sebab itu, studi analisis tingkat kerentanan wilayah pesisir di Kabupaten Demak diperlukan sebagai bahan pertimbangan pengelolaan wilayah pesisir dan mitigasi untuk mengurangi dampak yang ditimbulkan akibat kondisi dinamis lingkungan pesisir.

\section{MATERI DAN METODE}

\section{Lokasi Penelitian}

Wilayah kajian dalam penelitian ini meliputi wilayah pesisir Kabupaten Demak, Provinsi Jawa Tengah. Wilayah kajian mengikuti garis pantai sepanjang 67, $975 \mathrm{~km}$ yang membentang dari desa Babalan hingga desa Sriwulan yang berbatasan langsung dengan Laut Jawa.

\section{Pengumpulan Data}

Variabel fisik pesisir yang digunakan dalam penilian kerentanan pesisir Kabupaten Demak yaitu tata guna lahan (geomorfologi), elevasi pesisir, perubahan garis pantai, pasang surut, kenaikan muka air laut dan gelombang. Data yang digunakan dalam penelitian ini antara lain (1) peta tutupan lahan (2) peta rupa bumi Indonesia skala 1:25.000, (4) data DEMNAS, (5) data angin dan pasang surut dari BMKG Semarang, (6) Landsat 8 (7) data pendukung berupa data sebaran mangrove di Kabupaten Demak tahun 2019 (8) penelitian terdahulu. Perangkat lunak yang digunakan antara lain (1) ArcMap 10.4 untuk pengolahan data DEMNAS ,tutupan lahan, dan perubahan garis pantai juga analisis spasial, dan (2) Microsoft Excel untuk pengolahan pasang surut, kenaikan muak air laut, dan tabulasi data.

\section{Analisis Data}

Tahapan analisis data untuk menentukan tingkat kerentanan wilayah pesisir sebagai berikut:

1. Mengolah data setiap paramater sesuai dengan ketentuan kelas atau kategori kerentanannya.

2. Mengelompokkan data geomorfologi atau tutupan lahan,elevasi pesisir, perubahan garis pantai, tunggang pasang surut, kenaikan muka air laut, dan tinggi gelombang signifikan berdasarkan kelas atau kategori kerentanannya.

3. Analisis tingkat kerentanan secara spasial dengan melakukan overlay semua variabel vektor (geomorfologi atau tutupan lahan,elevasi pesisir, perubahan garis pantai, tunggang pasang surut, kenaikan muka air laut, dan tinggi gelombang signifikan) serta cakupan wilayah kajian sebagai pembatas. Analisis tingkat kerentanan wilayah pesisir dari bentuk geomorfologi dan elevasi wilayah pesisir Kota Demak kdianalisis berdasarkan perhitungan kriteria kerentanan (Tabel 1).

4. Perhitungan indeks kerentanan wilayah pesisir Kabupaten Demak ditentukan dengan mengkombinasikan nilai semua parameter untuk menghasilkan nilai indeksi kerentanan. 
Perhitungan nilai skor indeks kerentanan dilakukan berdasarkan konsep perhitungan nilai indeks kerentanan dalam metode Coastal Vulnerability Index (CVI). Metode CVI menerapkan pendekatan yang sederhana dalam penyediaan dasar numerik untuk klasifikasi bagian-bagian dari garis pantai terhadap perubahan fisik sehingga dapat digunakan dalam mengidentifikasi wilayah berisiko tinggi. Secara umum, indeks kerentanan berdasarkan persamaan berikut (Gornitz, 1991) :

$$
C V I=\sqrt{\frac{a x b x c x d x e x f}{6}}
$$

$\begin{array}{ll}\text { dengan } & \\ \text { CVI } & \text { : nilai indeks kerentanan } \\ \text { a } & \text { : Variabel geomorfologi pantai } \\ \text { b } & \text { : Variabel elevasi pesir } \\ \text { c } & \text { : Variabel perubahan garis pantai } \\ \text { d } & \text { : Variabel rata- rata tunggang pasut } \\ \text { e } & \text { : Variabel kenaikan muka ait laut } \\ \mathrm{f} & \text { : Variabel tinggi gelombang signifikan }\end{array}$

5. Pembagian tingkat kerentanan total didasarkan pada penelitian yang dilakukan oleh Gornitz dan White (1992) dimana kelas kerentanan tersebut dibagi berdasarkan persen dengan range antar kelas adalah 33\% dimana batas persentil 0-33\% merupakan kelas Tidak Rentan, 34\%- 67\% kelas Sedang, dan 67\%-100\% termasuk dalam kelas Rentan. Batas persentil pada penelitian ini diperoleh, jika nilai CVI kurang dari 0,377 dikatakan tidak rentan, nilai CVI berada antara 0,377 - 7,600 dalam kategori sedang, dan jika nilai CVI lebih dari 7,600 kategori rentan.

Tabel 1. Kriteria Tingkat Kerentanan Pesisir Berdasar Metode Coastal Vulnerability Index (CVI)

\section{SKOR}

\begin{tabular}{|c|c|c|c|c|c|}
\hline \multirow{3}{*}{ Parameter } & \\
\hline & $\begin{array}{c}\text { Tidak } \\
\text { Rentan }\end{array}$ & $\begin{array}{l}\text { Kurang } \\
\text { Rentan }\end{array}$ & Sedang & Rentan & $\begin{array}{l}\text { Sangat } \\
\text { Rentan }\end{array}$ \\
\hline & 1 & 2 & 3 & 4 & 5 \\
\hline Geomorfologi & $\begin{array}{l}\text { Bertebing } \\
\text { tinggi }\end{array}$ & $\begin{array}{l}\text { Bertebing } \\
\text { sedang, } \\
\text { pantai } \\
\text { berlekuk }\end{array}$ & $\begin{array}{l}\text { Bertebing } \\
\text { rendah, } \\
\text { dataran } \\
\text { alluvial }\end{array}$ & $\begin{array}{c}\text { Estuarine, } \\
\text { Laguna }\end{array}$ & $\begin{array}{c}\text { Pantai } \\
\text { berpasir, } \\
\text { Rawa, } \\
\text { Payau, } \\
\text { Paparan } \\
\text { lumpur, } \\
\text { Delta, } \\
\text { Mangrove, } \\
\text { Karang }\end{array}$ \\
\hline Elevasi (m) & $>30,0$ & $20,1-30,0$ & $10,1-20,0$ & $5,1-10,0$ & $0,0-5,0$ \\
\hline $\begin{array}{l}\text { Perubahan } \\
\text { garis pantai } \\
(\mathrm{m} / \mathrm{thn})\end{array}$ & $>2,0$ akresi & $\begin{array}{c}1,0-2,0 \\
\text { akresi }\end{array}$ & $\begin{array}{c}1,0--1,0 \\
\text { stabil }\end{array}$ & $\begin{array}{l}-1--2 \\
\text { abrasi }\end{array}$ & $<-2,0$ abrasi \\
\hline $\begin{array}{l}\text { Kenaikan } \\
\text { muka air laut } \\
(\mathrm{mm} / \mathrm{thn})\end{array}$ & $<-1,0$ & $-1,0-0,99$ & $1,0-2,0$ & $2,1-4,0$ & $>4,0$ \\
\hline $\begin{array}{l}\text { Kisaran pasut } \\
\text { rata- rata }(\mathrm{m})\end{array}$ & $\begin{array}{c}<1,0 \\
\text { microtidal }\end{array}$ & $1,0-1,9$ & $2,0-4,0$ & $4,1-6,0$ & $\begin{array}{c}>6,0 \\
\text { macrotidal }\end{array}$ \\
\hline
\end{tabular}




\begin{tabular}{cccccc}
\hline & \multicolumn{5}{c}{ SKOR } \\
\cline { 2 - 6 } Parameter & $\begin{array}{c}\text { Tidak } \\
\text { Rentan }\end{array}$ & $\begin{array}{c}\text { Kurang } \\
\text { Rentan }\end{array}$ & Sedang & Rentan & $\begin{array}{c}\text { Sangat } \\
\text { Rentan }\end{array}$ \\
\cline { 2 - 6 } & $\mathbf{1}$ & $\mathbf{2}$ & $\mathbf{3}$ & $\mathbf{4}$ & $\mathbf{5}$ \\
\hline $\begin{array}{c}\text { Tinggi } \\
\text { gelombang } \\
\text { signifikan } \\
(\mathrm{m})\end{array}$ & $0-2,9$ & $3,0-4,9$ & $5,0-5,9$ & $6,0-6,9$ & $>7,0$ \\
\hline
\end{tabular}

(Sumber: Gornitz and White, 1992)

6. Hasil analisa kerentanan pesisir Kabupaten Demak didapatkan parameter kerentanan yang paling bervariasi nilainya yaitu perubahan garis pantai. Sehingga dilakukan evaluasi perubahan garis pantai dari penelitian terdahulu oleh Sasmito dan Suprayogi (2017) dan dilakukan prediksi perubahan garis pantai untuk tahun 2021-2025 di Pesisir Kabupaten Demak.

\section{HASIL DAN PEMBAHASAN}

\section{Tingkat Kerentanan Pesisir Kabupaten Demak}

Pada tabel 1, indeks kerentanan pesisir dibagi menjadi tiga kelas yaitu kelas rentan, kelas sedang dan kelas tidak rentan. Pembagian kelas atau tingkat kerentan didasarkan pada penelitian yang dilakukan oleh Gornitz and White (1992) dimana kelas tersebut dibagi berdasarkan persen dengan range antar kelas adalah 33 persen. Hasil perhitungan Nilai CVI pada daerah penelitian dihasilkan dari pengolahan dan analisis skor paramater geomorfologi, elevasi pesisir, perubahan garis pantai, pasang surut, kenaikan muka air laut, dan gelombang yang mempengaruhi kerentanan seperti pada Tabel 2. Pada Tabel 2, terlihat bahwa terdapat 8 desa yang termasuk dalam kelas rentan dan 4 desa yang termasuk dalam kelas sedang.

Tabel 2. Hasil Perhitungan Indeks Kerentanan Pesisir Kabupaten Demak

\begin{tabular}{ccccccccc}
\hline \multirow{2}{*}{ Desa } & \multicolumn{1}{c}{\begin{tabular}{c} 
SKOR \\
\cline { 2 - 9 }
\end{tabular}} & $\begin{array}{c}\text { Geomor } \\
\text { fologi }\end{array}$ & Elevasi & $\begin{array}{c}\text { Perubahan } \\
\text { Garis } \\
\text { Pantai }\end{array}$ & $\begin{array}{c}\text { Pasang } \\
\text { Surut }\end{array}$ & $\begin{array}{c}\text { Kenaika } \\
\text { n Muka } \\
\text { Air Laut }\end{array}$ & Gelombang & Kelas \\
\hline Babalan & 5 & 5 & 1 & 1 & 5 & 1 & 4.564355 & sedang \\
\hline Berahan Wetan & 5 & 5 & 1 & 1 & 5 & 1 & 4.564355 & sedang \\
\hline Berahan Kulon & 5 & 5 & 1 & 1 & 5 & 1 & 4.564355 & sedang \\
\hline Wedung & 5 & 5 & 1 & 1 & 5 & 1 & 4.564355 & sedang \\
\hline Betahwalang & 5 & 5 & 5 & 1 & 5 & 1 & 10.20621 & rentan \\
\hline Purworejo & 5 & 5 & 5 & 1 & 5 & 1 & 10.20621 & rentan \\
\hline Morodemak & 5 & 5 & 5 & 1 & 5 & 1 & 10.20621 & rentan \\
\hline Tambakbulusan & 5 & 5 & 4 & 1 & 5 & 1 & 9.128709 & rentan \\
\hline Surodadi & 5 & 5 & 5 & 1 & 5 & 1 & 10.20621 & rentan \\
\hline Timbulsloko & 5 & 5 & 5 & 1 & 5 & 1 & 10.20621 & rentan \\
\hline Bedono & 5 & 5 & 5 & 1 & 5 & 1 & 10.20621 & rentan \\
\hline Sriwulan & 5 & 5 & 5 & 1 & 5 & 1 & 10.20621 & rentan \\
\hline
\end{tabular}

Berdasarkan hasil perhitungan nilai CVI pada keenam parameter tersebut, diintegrasikan dalam bentuk spasial seperti pada Gambar 1 yang menunjukkan wilayah dengan keadaan sedang dan rentan berdasarkan rentang nilai CVI. 


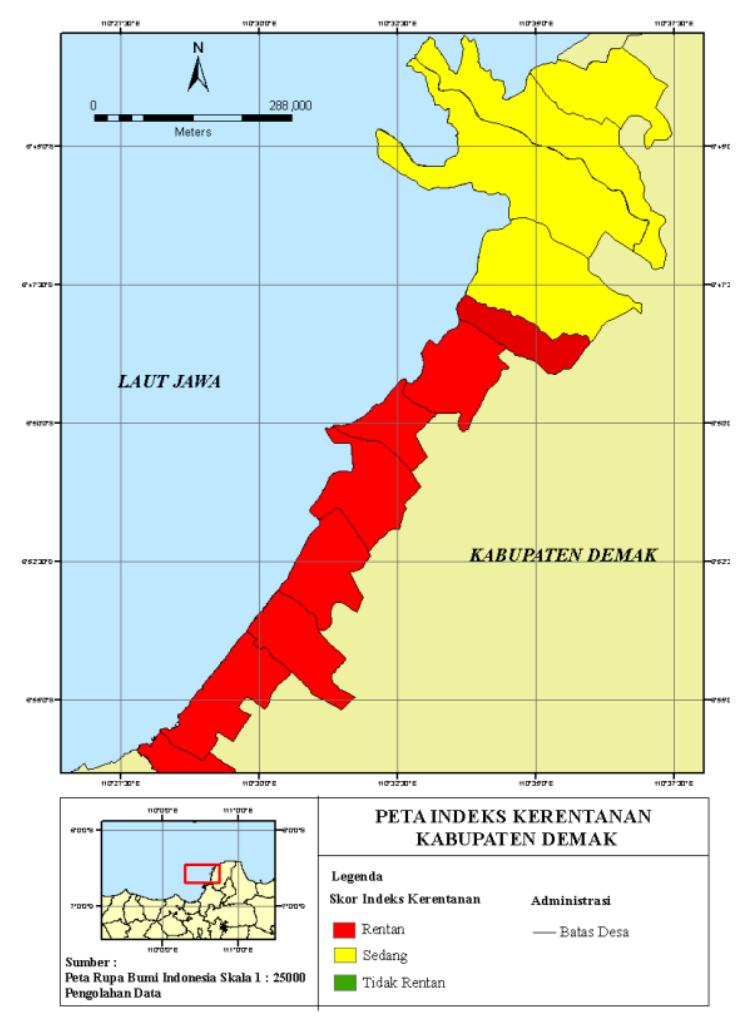

\section{Gambar 1. Peta Peta Indeks Kerentanan Kabupaten Demak}

(Sumber : Hasil Pengolahan Data, 2020)

Berdasarkan hasil analisa diketahui bahwa parameter geomorfologi, elevasi, pasang surut, kenaikan muka air laut dan gelombang memiliki kelas kerentanan yang sama pada tiap desa. Sedangkan pada parameter perubahan garis pantai memiliki kelas yang beragam yaitu kelas rentan, sangat rentan dan sangat tidak rentan dimana terjadi akresi dan erosi pantai. Sehingga dilakukan analisa lebih lanjut dengan mengevaluasi prediksi kerentanan pesisir berdasar perubahan garis pantai yang dilakukan oleh Sasmito dan Suprayogi (2017).

Analisa perhtitungan perubahan garis pantai dilakukan di 4 kecamatan yaitu, Kecamatan Wedung, Bonang, Karangtengah dan Sayung. Setiap kecamatan terdapat 4 transek yang dianalisis perubahan jarak abrasi dan akresi yang paling signifikan. Tanda (+) menandakan terjadinya akresi pada lokasi tersebut dan tanda (-) menandakan adanya abrasi di lokasi tersebut. Gambar 2 adalah peta lokasi titik transek di Kecamatan Wedung

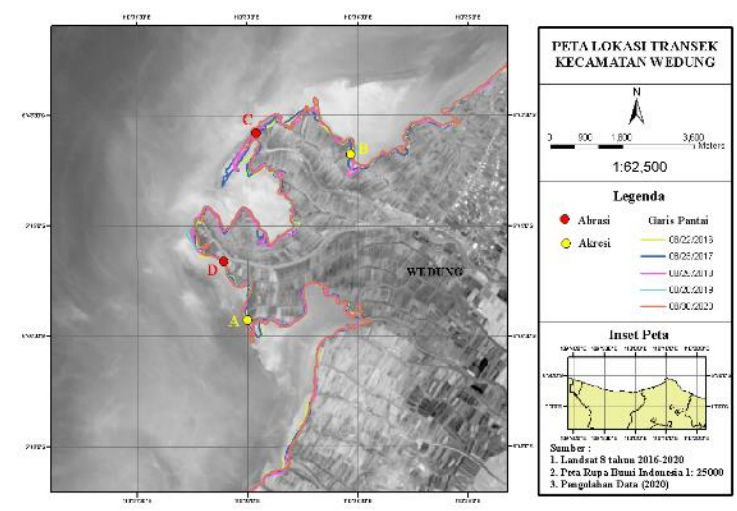

Gambar 2. Peta Lokasi Transek di Kecamatan Wedung

(Sumber : Hasil Pengolahan Data, 2020) 
Gambar 2 menunjukkan lokasi titik transek A, B, C dan D yang berada di Kecamatan Wedung. Jarak abrasi dan akresi signifikan di tiap transek dianalisis dengan DSAS yang ditunjukkan pada tabel 3 hingga 6 dengan nilai perubahan positif (+) menujukkan terjadinya akresi, dan nilai perubahan negatif (-) menunjukkan terjadinya abrasi.

Tabel 3. Perubahan Jarak Garis Pantai Transek A

\begin{tabular}{|c|c|c|c|}
\hline \multicolumn{4}{|c|}{ Transek A } \\
\hline Intersect X & Intersect Y & Shoreline ID & Distance \\
\hline 450243.57 & 9251700.73 & $8 / 22 / 2016$ & 120.79 \\
\hline 450208.76 & 9251628.2 & $8 / 23 / 2017$ & 123.38 \\
\hline 450162.18 & 9251665.49 & $8 / 25 / 2018$ & 125.86 \\
\hline 450168.83 & 9251649.98 & $8 / 28 / 2019$ & 127.29 \\
\hline 450317.31 & 9251199.27 & $8 / 30 / 2020$ & 173.51 \\
\hline \multicolumn{3}{|c|}{ Total Perubahan } & 52.72 \\
\hline
\end{tabular}

Tabel 5. Perubahan Jarak Garis Pantai Transek C

\begin{tabular}{|c|c|c|c|}
\hline \multicolumn{5}{|c|}{ Transek C } \\
\hline Intersect X & Intersect Y & Shoreline ID & Distance \\
\hline 450237.3 & 9255529.44 & $8 / 22 / 2016$ & -128 \\
\hline 450338.59 & 9255467.12 & $8 / 23 / 2017$ & -134.2 \\
\hline 450349.76 & 9255444.93 & $8 / 25 / 2018$ & -147.63 \\
\hline 450729.65 & 9255389.57 & $8 / 28 / 2019$ & -167.07 \\
\hline 450348.6 & 9255427.99 & $8 / 30 / 2020$ & -195.01 \\
\hline \multicolumn{5}{|c|}{ Total Perubahan } & -67.01 \\
\hline
\end{tabular}

Tabel 4. Perubahan Jarak Garis Pantai Transek B

\begin{tabular}{|c|c|c|c|}
\hline \multicolumn{4}{|c|}{ Transek B } \\
\hline Intersect X & Intersect Y & Shoreline ID & Distance \\
\hline 452791.8 & 9255365.1 & $8 / 22 / 2016$ & 202.57 \\
\hline 452813.2 & 9255360.4 & $8 / 23 / 2017$ & 205.77 \\
\hline 452913.5 & 9255401.6 & $8 / 25 / 2018$ & 209.16 \\
\hline 452986.8 & 9255439.9 & $8 / 28 / 2019$ & 211.17 \\
\hline 452989.5 & 9255438.3 & $8 / 30 / 2020$ & 212.37 \\
\hline \multicolumn{3}{|c|}{ Total Perubahan } & 9.8 \\
\hline
\end{tabular}

Tabel 6. Perubahan Jarak Garis Pantai Transek D

\begin{tabular}{|c|c|c|c|}
\hline \multicolumn{4}{|c|}{ Transek D } \\
\hline Intersect X & Intersect $\mathrm{Y}$ & Shoreline ID & Distance \\
\hline 449434.12 & 9253106.5 & $8 / 22 / 2016$ & 7.82 \\
\hline 449410.95 & 9253122.5 & $8 / 23 / 2017$ & 0.92 \\
\hline 449379.21 & 9253097.5 & $8 / 25 / 2018$ & -0.56 \\
\hline 449394.91 & 9253109.7 & $8 / 28 / 2019$ & -1.66 \\
\hline 449366.93 & 9253120.7 & $8 / 30 / 2020$ & -9.04 \\
\hline \multicolumn{3}{|c|}{ Total Perubahan } & -16.86 \\
\hline
\end{tabular}

Gambar 3 adalah peta lokasi titik transek di Kecamatan Bonang yang mengalami perubahan jarak abrasi dan akresi yang paling signifikan.

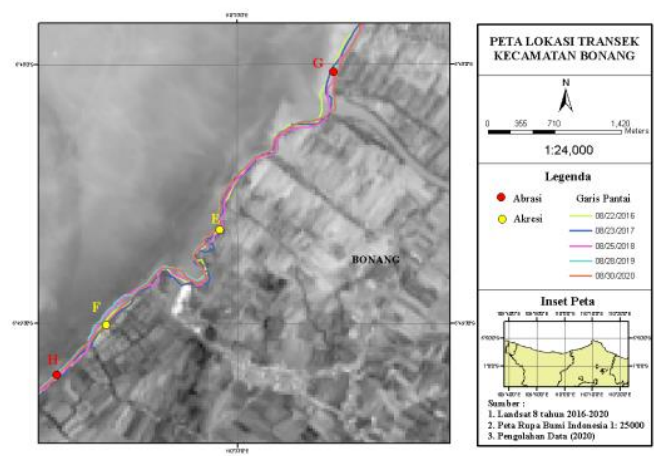

Gambar 3. Peta Lokasi Transek di Kecamatan Bonang (Pengolahan Data, 2020)

Gambar 3 menunjukkan lokasi titik transek E, F, G dan H yang berada di Kecamatan Bonang. Jarak abrasi dan akresi signifikan di tiap transek dianalisis dengan DS AS yang ditunjukkan pada tabel 7 hingga 10 dengan nilai perubahan positif (+) menujukkan terjadinya akresi, dan nilai perubahan negatif (-) menunjukkan terjadinya abrasi. 
Tabel 7. Perubahan Jarak Garis Pantai Transek E

\begin{tabular}{|c|c|c|c|}
\hline \multicolumn{4}{|c|}{ Transek E } \\
\hline Intersect X & Intersect Y & Shoreline ID & Distance \\
\hline 449860.04 & 9246243.44 & $8 / 22 / 2016$ & 18.61 \\
\hline 449852.63 & 9246190.99 & $8 / 23 / 2017$ & 39.21 \\
\hline 449859.42 & 9246193.81 & $8 / 25 / 2018$ & 42.31 \\
\hline 449853.17 & 9246374.88 & $8 / 28 / 2019$ & 43.43 \\
\hline 449857.66 & 9246365.97 & $8 / 30 / 2020$ & 46.07 \\
\hline \multicolumn{3}{|c|}{ Total Perubahan } & 27.46 \\
\hline
\end{tabular}

Tabel 9. Perubahan Jarak Garis Pantai Transek G

\begin{tabular}{|c|c|c|c|}
\hline \multicolumn{4}{|c|}{ Transek G } \\
\hline Intersect X & Intersect $\mathrm{Y}$ & Shoreline ID & Distance \\
\hline 451228.87 & 9248142.96 & $8 / 22 / 2016$ & -82.42 \\
\hline 451223.33 & 9248056.94 & $8 / 23 / 2017$ & -129.28 \\
\hline 451244.11 & 9247989.86 & $8 / 25 / 2018$ & -141.98 \\
\hline 451277 & 9247840.86 & $8 / 28 / 2019$ & -158.98 \\
\hline 451294.27 & 9247841.46 & $8 / 30 / 2020$ & -172.88 \\
\hline \multicolumn{3}{|c|}{ Total Perubahan } & -90.46 \\
\hline
\end{tabular}

Tabel 8. Perubahan Jarak Garis Pantai Transek F

\begin{tabular}{|c|c|c|c|}
\hline \multicolumn{5}{|c|}{ Transek F } \\
\hline Intersect X & Intersect Y & Shoreline ID & Distance \\
\hline $8 / 22 / 2016$ & 448881.89 & 9245606.6 & -15.25 \\
\hline $8 / 23 / 2017$ & 448888.7 & 9245576.71 & -9.21 \\
\hline $8 / 25 / 2018$ & 448828.66 & 9245614.61 & -3.29 \\
\hline $8 / 28 / 2019$ & 448750.23 & 9245547.68 & -5.18 \\
\hline $8 / 30 / 2020$ & 448840.86 & 9245536.87 & -2.61 \\
\hline \multicolumn{5}{|c|}{ Total Perubahan } & 12.64 \\
\hline
\end{tabular}

Tabel 10. Perubahan Jarak Garis Pantai Transek H

\begin{tabular}{|c|c|c|c|}
\hline \multicolumn{4}{|c|}{ Transek H } \\
\hline Intersect X & Intersect Y & Shoreline ID & Distance \\
\hline $8 / 22 / 2016$ & 448266.49 & 9244934.45 & 26.82 \\
\hline $8 / 23 / 2017$ & 448495.03 & 9245128.88 & 21.68 \\
\hline $8 / 25 / 2018$ & 448261.01 & 9244918.67 & 24.97 \\
\hline $8 / 28 / 2019$ & 448326.95 & 9245016.92 & 25.17 \\
\hline $8 / 30 / 2020$ & 448407.84 & 9245074.14 & 20.05 \\
\hline \multicolumn{3}{|c|}{ Total Perubahan } & -6.77 \\
\hline
\end{tabular}

Gambar 4 adalah peta lokasi titik transek di Kecamatan Karang Tengah yang mengalami perubahan jarak abrasi dan akresi yang paling signifikan

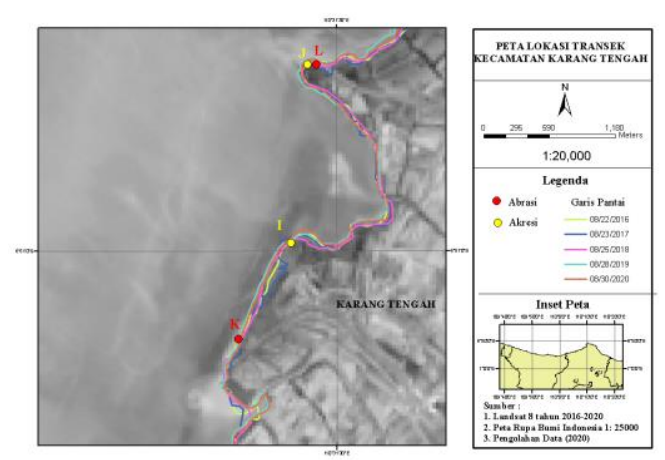

Gambar 4. Peta Lokasi Transek di Kecamatan Karang Tengah (Pengolahan Data, 2020)

Gambar 4 menunjukkan lokasi titik transek I, J, K dan L yang berada di Kecamatan Karang Tengah. Jarak abrasi dan akresi signifikan di tiap transek dianalisis dengan DSAS yang ditunjukkan pada tabel 11 hingga 14 dengan nilai perubahan positif (+) menujukkan terjadinya akresi, dan nilai perubahan negatif (-) menunjukkan terjadinya abrasi. 
Tabel 11. Perubahan Jarak Garis Pantai Transek I

\begin{tabular}{|c|c|c|c|}
\hline \multicolumn{5}{|c|}{ Transek I } \\
\hline Intersect X & Intersect Y & Shoreline ID & Distance \\
\hline $8 / 22 / 2016$ & 447617.55 & 9242925.67 & -11.85 \\
\hline $8 / 23 / 2017$ & 447659.813 & 9242953.41 & -9.8 \\
\hline $8 / 25 / 2018$ & 447619.822 & 9242895.33 & -8.94 \\
\hline $8 / 28 / 2019$ & 447624.224 & 9242943.04 & -8.13 \\
\hline $8 / 30 / 2020$ & 447634.055 & 9242921.72 & -14 \\
\hline \multicolumn{5}{|c|}{ Total Perubahan } & -2.15 \\
\hline
\end{tabular}

Tabel 13. Perubahan Jarak Garis Pantai Transek K

\begin{tabular}{|c|c|c|c|}
\hline \multicolumn{5}{|c|}{ Transek K } \\
\hline Intersect X & Intersect Y & Shoreline ID & Distance \\
\hline $8 / 22 / 2016$ & 446620.27 & 9241975 & -28.9 \\
\hline $8 / 23 / 2017$ & 446639.991 & 9241920.6 & -29.43 \\
\hline $8 / 25 / 2018$ & 446557.871 & 9241856.9 & -31.65 \\
\hline $8 / 28 / 2019$ & 446615.87 & 9241938 & -31.78 \\
\hline $8 / 30 / 2020$ & 446646.605 & 9241951.3 & -34.39 \\
\hline \multicolumn{5}{|c|}{ Total Perubahan } & -5.49 \\
\hline
\end{tabular}

Tabel 12. Perubahan Jarak Garis Pantai Transek J

\begin{tabular}{|c|c|c|c|}
\hline \multicolumn{4}{|c|}{ Transek J } \\
\hline Intersect X & Intersect Y & Shoreline ID & Distance \\
\hline $8 / 22 / 2016$ & 447199.94 & 9244428.18 & -6.71 \\
\hline $8 / 23 / 2017$ & 447208.32 & 9244381.63 & -5.47 \\
\hline $8 / 25 / 2018$ & 447212.02 & 9244360.41 & -5.3 \\
\hline $8 / 28 / 2019$ & 447200.23 & 9244330.14 & 1.61 \\
\hline $8 / 30 / 2020$ & 447227 & 9244322.62 & 11.35 \\
\hline \multicolumn{5}{|c|}{ Total Perubahan } & 18.06 \\
\hline
\end{tabular}

Tabel 14. Perubahan Jarak Garis Pantai Transek L

\begin{tabular}{|c|c|c|c|}
\hline \multicolumn{4}{|c|}{ Transek L } \\
\hline Inter: & Intersect $\mathrm{Y}$ & Shoreline ID & Distar \\
\hline $8 / 22 /$ & 447326.06 & 924 & \\
\hline $8 / 23 /$ & 447352.3 & 924 & -22.61 \\
\hline $8 / 25 / 2018$ & 447420.41 & 9244 & -15.91 \\
\hline $8 / 28 / 2$ & 447356.77 & 924 & -26.16 \\
\hline $8 / 30 /$ & 447119.27 & 9242 & -27.54 \\
\hline \multicolumn{3}{|c|}{ Total Perubahan } & -11.12 \\
\hline
\end{tabular}

Gambar 23 adalah peta lokasi titik transek di Kecamatan Sayung yang mengalami perubahan jarak abrasi dan akresi yang paling signifikan.

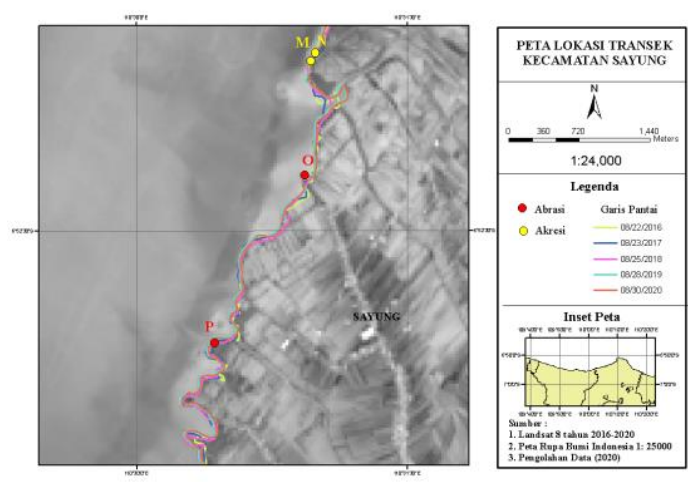

Gambar 51. Peta Lokasi Transek di Kecamatan Sayung (Pengolahan Data, 2020)

Gambar 5 menunjukkan lokasi titik transek M, N, O dan P yang berada di Kecamatan Sayung. Jarak abrasi dan akresi signifikan di tiap transek dianalisis dengan DS AS yang ditunjukkan pada Tabel 
15 hingga 18 dengan nilai perubahan positif, sehingga dari nilai perubahan jarak garis pantai tiap transek yang dianalisa dalam kurun waktu 2016-2020 didapatkan data seperti pada Tabel 19 dibawah.

Tabel 15. Perubahan Jarak Garis Pantai Transek M

\begin{tabular}{|c|c|c|c|}
\hline \multicolumn{5}{|c|}{ Transek M } \\
\hline Intersect X & Intersect Y & Shoreline ID & Distance \\
\hline $8 / 22 / 2016$ & 446584.89 & 9241147.5 & -12.78 \\
\hline $8 / 23 / 2017$ & 446662.747 & 9241265.48 & -11.96 \\
\hline $8 / 25 / 2018$ & 446728.405 & 9241242.56 & -10.22 \\
\hline $8 / 28 / 2019$ & 446675.115 & 9241234.21 & -9.75 \\
\hline $8 / 30 / 2020$ & 446724.944 & 9241262.74 & -9.42 \\
\hline \multicolumn{5}{|c|}{ Total Perubahan } & 3.36 \\
\hline
\end{tabular}

Tabel 17. Perubahan Jarak Garis Pantai Transek O

\begin{tabular}{|c|c|c|c|}
\hline \multicolumn{5}{|c|}{ Transek O } \\
\hline Intersect X & Intersect Y & Shoreline ID & Distance \\
\hline $8 / 22 / 2016$ & 446245.359 & 9240107.2 & -11.77 \\
\hline $8 / 23 / 2017$ & 446549.261 & 9240602.3 & -14.01 \\
\hline $8 / 25 / 2018$ & 446271.497 & 9240240.6 & -15.53 \\
\hline $8 / 28 / 2019$ & 446567.055 & 9240656.4 & -33.07 \\
\hline $8 / 30 / 2020$ & 446578.173 & 9240628.3 & -34.52 \\
\hline \multicolumn{5}{|c|}{ Total Perubahan } & -22.75 \\
\hline
\end{tabular}

Tabel 16. Perubahan Jarak Garis Pantai Transek N

\begin{tabular}{|c|c|c|c|}
\hline \multicolumn{5}{|c|}{ Transek N } \\
\hline Intersect X & Intersect Y & Shoreline ID & Distance \\
\hline $8 / 22 / 2016$ & 446666.78 & 9241222.3 & -7.56 \\
\hline $8 / 23 / 2017$ & 446654.03 & 9241214.72 & -5.38 \\
\hline $8 / 25 / 2018$ & 446643.37 & 9241155.88 & -4.8 \\
\hline $8 / 28 / 2019$ & 446636.1 & 9241208.88 & -4.43 \\
\hline $8 / 30 / 2020$ & 446588.37 & 9240932.85 & -4.1 \\
\hline \multicolumn{5}{|c|}{ Total Perubahan } & 3.46 \\
\hline
\end{tabular}

Tabel 18. Perubahan Jarak Garis Pantai Transek P

\begin{tabular}{|c|c|c|c|}
\hline \multicolumn{4}{|c|}{ Transek P } \\
\hline Intersect X & Intersect $\mathrm{Y}$ & Shoreline ID & Distance \\
\hline $8 / 22 / 2016$ & 443276.35 & 9234574.67 & -1.9 \\
\hline $8 / 23 / 2017$ & 442947.43 & 9234524.2 & -3.75 \\
\hline $8 / 25 / 2018$ & 443027.13 & 9234512.9 & -3.83 \\
\hline $8 / 28 / 2019$ & 443247.76 & 9234575.75 & -7.43 \\
\hline $8 / 30 / 2020$ & 443179.74 & 9234483.92 & -9.81 \\
\hline \multicolumn{3}{|c|}{ Total Perubahan } & -7.91 \\
\hline
\end{tabular}

Tabel 19. Jarak Perubahan Garis Pantai dari tahun 2016-2020 dengan analisa Digital Shoreline Analysis System (DSAS)

\begin{tabular}{cccccc}
\hline \multirow{2}{*}{ Transek } & \multicolumn{5}{c}{ TAHUN } \\
\cline { 2 - 6 } & $\mathbf{2 0 1 6}$ & $\mathbf{2 0 1 7}$ & $\mathbf{2 0 1 8}$ & $\mathbf{2 0 1 9}$ & $\mathbf{2 0 2 0}$ \\
\hline A & 120.79 & 123.38 & 125.86 & 127.29 & 173.51 \\
\hline B & 202.57 & 205.77 & 209.16 & 211.17 & 212.37 \\
\hline C & -128 & -134.2 & -147.63 & -167.07 & -195.01 \\
\hline D & 7.82 & 0.92 & -0.56 & -1.66 & -9.04 \\
\hline E & 18.61 & 39.21 & 42.31 & 43.43 & 46.07 \\
\hline F & -15.25 & -9.21 & -3.29 & -5.18 & -2.61 \\
\hline G & -82.42 & -129.28 & -141.98 & -158.98 & -172.88 \\
\hline H & 26.82 & 21.68 & 24.97 & 25.17 & 20.05 \\
\hline I & -11.85 & -9.8 & -8.94 & -8.13 & -14 \\
\hline J & -6.71 & -5.47 & -5.3 & 1.61 & 11.35 \\
\hline K & -28.9 & -29.43 & -31.65 & -31.78 & -34.39 \\
\hline L & -16.42 & -22.61 & -15.91 & -26.16 & -27.54 \\
\hline M & -12.78 & -11.96 & -10.22 & -9.75 & -9.42 \\
\hline N & -7.56 & -5.38 & -4.8 & -4.43 & -4.1 \\
\hline O & -11.77 & -14.01 & -15.53 & -33.07 & -34.52 \\
\hline P & -1.9 & -3.75 & -3.83 & -7.43 & -9.81 \\
\hline
\end{tabular}

Sumber : Pengolahan Data, 2020 
Sedangkan pada penelitian Sasmito dan Suprayogi (2017) dilakukan prediksi perubahan garis pantai di tahun yang sama yaitu pada tahun 2016-2020 yang disajikan pada tabel 20.

Tabel 20. Jarak Perubahan Garis Pantai dari tahun 2016-2020 dengan analisa Digital Shoreline Analysis System (DSAS)

\begin{tabular}{cccccc}
\hline Transek & \multicolumn{5}{c}{ TAHUN } \\
\cline { 2 - 6 } & $\mathbf{2 0 1 6}$ & $\mathbf{2 0 1 7}$ & $\mathbf{2 0 1 8}$ & $\mathbf{2 0 1 9}$ & $\mathbf{2 0 2 0}$ \\
\hline A & 120.79 & 123.38 & 125.86 & 127.29 & 173.51 \\
\hline B & 202.57 & 205.77 & 209.16 & 211.17 & 212.37 \\
\hline C & -128 & -134.2 & -147.63 & -167.07 & -195.01 \\
\hline D & 7.82 & 0.92 & -0.56 & -1.66 & -9.04 \\
\hline E & 18.61 & 39.21 & 42.31 & 43.43 & 46.07 \\
\hline F & -15.25 & -9.21 & -3.29 & -5.18 & -2.61 \\
\hline G & -82.42 & -129.28 & -141.98 & -158.98 & -172.88 \\
\hline H & 26.82 & 21.68 & 24.97 & 25.17 & 20.05 \\
\hline I & -11.85 & -9.8 & -8.94 & -8.13 & -14 \\
\hline J & -6.71 & -5.47 & -5.3 & 1.61 & 11.35 \\
\hline K & -28.9 & -29.43 & -31.65 & -31.78 & -34.39 \\
\hline L & -16.42 & -22.61 & -15.91 & -26.16 & -27.54 \\
\hline M & -12.78 & -11.96 & -10.22 & -9.75 & -9.42 \\
\hline N & -7.56 & -5.38 & -4.8 & -4.43 & -4.1 \\
\hline O & -11.77 & -14.01 & -15.53 & -33.07 & -34.52 \\
\hline P & -1.9 & -3.75 & -3.83 & -7.43 & -9.81
\end{tabular}

Dari hasil pengolahan data tersebut, dapat kita lihat bahwa nilai trend perubahan garis pantai memiliki nilai yang berbeda dari hasil prediksi penelitian yang dilakukan oleh Sasmito dan Suprayogi (2017). Untuk itu, dilakukan perhitungan error dengan metode MRE dan memiliki akurasi dari hasil prediksi sebesar $96.898 \%$

Hasil perhitungan perubahan jarak garis pantai dapat diolah untuk mengetahui prediksi perubahan garis pantai untuk masa yang akan datang, yaitu untuk tahun 2021-2025. Prediksi ini dilakukan pada transek yang telah dianalisis sebelumnya, dari transek A hingga transek P yang terdapat di 4 kecamatan di sepanjang pesisir Demak. Hasil analisis regresi dapat dilihat pada Lampiran 1 . Hasil prediksi perubahan jarak garis pantai terdapat pada tabel 21.

Dari hasil prediksi tersebut dapat dilihat bahwa kecenderungan perubah an garis pantai di pesisir Kabupaten Demak adalah erosi pantai dibandingan akresi. Perubahan garis pantai akan memberikan pengaruh negatif terhadap daerah pesisir apabila perubahannya tersebut berupa pengurangan luas daratan (abrasi). Kecepatan perubahan garis pantai juga dipengaruhi oleh faktor geomorfologi. Geomorfologi pesisir Kabupaten Demak yang merupakan wilayah yang memiliki elevasi yang sangat rendah, juga semakin berkurangnya tutupan lahan mangrove di tiap tahunnya, menyebabkan wilayah pesisir Demak menjadi sangat rentan terhadap bencana seperti banjir rob yang setiap harinya menggenangi rumah dan jalan di desa.

Hasil persebaran wilayah kerentanan pesisir di pesisir Kabupaten Demak yang diperoleh diharapkan dapat menjadi pertimbangan dalam pengelolaan wilayah pesisir, khususnya untuk mitigasi bencana di pesisir Kabupaten Demak . Sehingga, pengelolaan wilayah pesisir yang terpadu ini dapat menjadi bahan pertimbangan dalam setiap pemanfaatan sumberdaya yang berada di wilayah pesisir dengan tetap memperhatikan lingkungan. 
Tabel 21. Prediksi Trend Perubahan Garis Pantai Tahun 2021-2025

\begin{tabular}{ccccccc}
\hline Kecamatan & Transek & \multicolumn{7}{c}{ TAHUN } \\
\cline { 2 - 7 } & & $\mathbf{2 0 2 1}$ & $\mathbf{2 0 2 2}$ & $\mathbf{2 0 2 3}$ & $\mathbf{2 0 2 4}$ & $\mathbf{2 0 2 5}$ \\
\hline \multirow{3}{*}{ Wedung } & $\mathrm{A}$ & 166.635 & 177.57 & 188.505 & 199.44 & 210.375 \\
\cline { 2 - 7 } & $\mathrm{B}$ & 215.7 & 218.2 & 220.7 & 223.2 & 225.7 \\
\cline { 2 - 7 } & $\mathrm{C}$ & -204.469 & -221.158 & -237.847 & -254.536 & -271.225 \\
\cline { 2 - 7 } Bonang & $\mathrm{D}$ & -11.43 & -15.06 & -18.69 & -22.32 & -25.95 \\
\cline { 2 - 7 } & $\mathrm{E}$ & 55.194 & 61.108 & 67.022 & 72.936 & 78.85 \\
\cline { 2 - 7 } & $\mathrm{F}$ & 30.015 & 35.73 & 41.445 & 47.16 & 52.875 \\
\cline { 2 - 7 } & $\mathrm{G}$ & -200.302 & -221.364 & -242.426 & -263.488 & -284.55 \\
\hline \multirow{3}{*}{ Karangtengah } & $\mathrm{H}$ & 20.695 & 19.69 & 18.685 & 17.68 & 16.675 \\
\cline { 2 - 7 } & $\mathrm{I}$ & -14.965 & -16.43 & -17.895 & -19.36 & -20.825 \\
\cline { 2 - 7 } & $\mathrm{J}$ & 19.11 & 22.92 & 26.73 & 30.54 & 34.35 \\
\cline { 2 - 7 } & $\mathrm{K}$ & -35.193 & -36.526 & -37.859 & -39.192 & -40.525 \\
\hline \multirow{3}{*}{ Sayung } & $\mathrm{L}$ & -29.459 & -32.038 & -34.617 & -37.196 & -39.775 \\
\cline { 2 - 7 } & $\mathrm{M}$ & -8.147 & -7.254 & -6.361 & -5.468 & -4.575 \\
\cline { 2 - 7 } & $\mathrm{N}$ & -2.873 & -2.086 & -1.299 & -0.512 & 0.275 \\
\cline { 2 - 7 } & $\mathrm{O}$ & -41.576 & -48.032 & -54.488 & -60.944 & -67.4 \\
\cline { 2 - 7 } & $\mathrm{P}$ & -11.15 & -13.1 & -15.05 & -17 & -18.95 \\
\hline
\end{tabular}

(Pengolahan Data, 2020)

\section{KESIMPULAN}

Tingkat kerentanan pesisir Kabupaten Demak menggunakan metode CVI berada di dua kategori yaitu sedang dan rentan. Kategori sedang terletak di 4 desa di kecamatan Wedung yaitu desa Babalan, Berahan Kulon, Berahan Wetan dan Wedung dengan nilai CVI 4,564. Kategori rentan terletak di desa Betahwalang, Purworejo, Morodemak yang berada di Kecamatan Bonang lalu di desa Surodadi, Timbulsloko, Bedono dan Sriwulan yang berada di Kecamatan Sayung denagan nilai CVI sebesar 10,2061, dan desa Tambakbulusan yang berada di Kecamatan Karang Tengah dengan nilai CVI sebesar 9,281 .

\section{DAFTAR PUSTAKA}

Gornitz, V. M. 1991. Global Coastal Hazards from Future Sea Level Rise. Palaeogeography, Palaeoclimatology, Palaeoecology (Global and Planetary Change Section). 89: 379-398.

Gornitz, V. M., dan T. W. White. 1992. A Coastal Hazard Data Base for The US East Coast. ORNL/CDIAC-45, NDP-043A. Oak Ridge National Laboratory, Oak Ridge. Tennessee.Gornitz dan Kanciruk.

Kasim, Faizal dan Vincentius P.Siregar .2012. Penilaian Kerentanan Pantai Menggunakan Metode Integrasi CVI-MCA Studi Kasus Pantai Indramayu. Forum Geografi. 26 (1) : 65.

Marfai, M. A., \& King, L. 2008. Potential Vulnerability Implications of Coastal Inundation due to Sea Level Rise The Coastal Zone of Semarang City, Indonesia. Environmental Geology. 54(6) : 1235 1245.

Sasmito, B., \& Suprayogi, A. 2017. Kajian Kerentanan Ekosistem Pesisir Kabupaten Demak Berdasar Perubahan Garis Pantai dengan Teknologi Penginderaan Jauh dan Sistem Informasi Geografis. Teknik. 38(1) :13-20.

Sanjoto, T. B., Sunarko, S., \& Parman, S. 2016. Tanggap Diri Masyarakat Pesisir dalam Menghadapi Bencana Erosi Pantai (Studi Kasus Masyarakat Desa Bedono Kabupaten Demak). Jurnal Geografi: Media Informasi Pengembangan dan Profesi Kegeografian, 13(1): 90-100.

Wirasatriya, A. 2005. Kajian Kenaikan Muka Laut Sebagai Landasan Penanggulangan Rob di Pesisir Kota Semarang (Doctoral dissertation), Program Pasca Sarjana Universitas Diponegoro. 